\title{
The Evolution of Relational Property Rights: A Case of Chinese Rural Land Reform
}

\author{
Shitong Qiao* E Frank Upham**
}

I. INTRODUCTION. 2480

II. IN REM Property AND THE EVOLUTION OF PROPERTY

RIGHTS. 2481

III. RELATIONAL Property AND BotTOM-Up InSTITUTIONAL

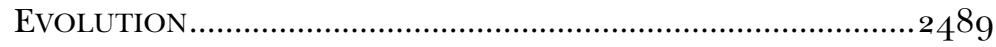

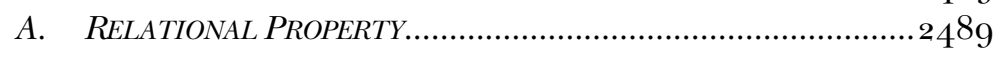

B. BOTTOM-UP INSTITUTIONAL EVOLUTION ...............................2492

C. FROM CLOSE-KNIT COMMUNITY TO UNBOUNDED NETWORK OF SOCIAL RELATIONS.

IV. Chinese Rural Land Reform: The Evolution of Property

RELATIONS.

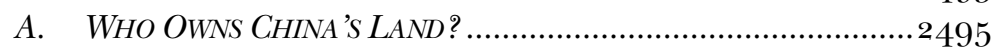

1. The Collective's Ownership.....................................2496

2. Farmers' Use Right to Rural Land .............................2496

3. State Monopoly on Rural-Urban Land

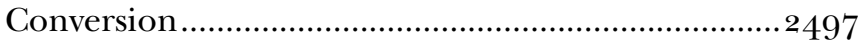

B. SMALL PROPERTY: A ONE-STICK EVOLUTION........................2498

\footnotetext{
* Assistant Professor, University of Hong Kong Faculty of Law; J.S.D. (expected May 2015 ), Yale Law School.

** Wilf Family Professor of Property Law, NYU School of Law.

Empirical research for this Essay was conducted by Qiao. This Essay was written jointly. The authors would like to thank Richard Brooks, Ruoying Chen, Richard Epstein, Henry Smith, Katrina M. Wyman, and especially Yun-chien Chang, and other participants of the Symposium for comments and suggestions. Shitong Qiao also thanks Robert Ellickson and participants of the Governing Access to Essential Resources workshop at Columbia Law School, in particular Hanoch Dagan and Katharina Pistor, for discussions on the concept of property rights.
} 
1. Social Relations (Not Law) Decide Property

Rights

2. The Same Market, Differentiated Property

Relations .2504

V. CONCLUSION 2506

\section{INTRODUCTION}

The most notable, or at least the most noted, form of property evolution has been the transfer of exclusive rights from collectives to individuals and vice versa. The competition between individual and collective property, according to Harold Demsetz, was a main theme of the 2oth century. ${ }^{1}$ Attention has been primarily on the radical property reforms that resulted in the shift of exclusive control over resources from one to another, such as the farm collectivization in Soviet Union or the establishment of the People's Communes in Mao's China and their reversals. ${ }^{2}$ It is undeniably true that a sudden and fundamental change in the form of ownership of an entire society or economic sector is exciting. That is perhaps why the literature on the evolution of property rights has focused on the transition from communal to private, or the reverse. 3 Such radical moments, however, constitute only a small part of history. For the most part, property rights evolve quietly and incrementally, which is hard to explain if we take exclusive rights as the core of property, or, to put it more generally, if we are focusing solely on the question of who owns the things.4

This Essay argues that the right to exclude is not always at the heart of property evolution, and, further, that other sticks in the bundle of property rights can play a central role in property evolution. As we demonstrate with the Chinese example, the metaphor of "bundle of rights" can better capture the nuanced, flexible, and idiosyncratic processes that have actually characterized the evolution of property rights.

To describe the evolution of property rights in China, we employ the concept of relational property. It is a concept that is heavily influenced by Joseph William Singer's "social relations model" 5 and Ian Macneil's

1. See generally Harold Demsetz, Toward a Theory of Property Rights II: The Competition Between Private and Collective Ownership, 31 J. LeGAL STUd. S653 (2002).

2. Robert C. Ellickson, Property in Land, 102 YALE L.J. 1315, 1318 (1993).

3. See generally Thomas W. Merrill, Introduction: The Demsetz Thesis and the Evolution of Property Rights, $3^{1}$ J. LEGAL STUD. S331 (2002) (summarizing scholarship in response to the Demsetz thesis).

4. See generally Henry E. Smith, Property as the Law of Things, 125 HARV. L. REV. 1691 (2012) (suggesting property law is best understood as a system of laws with many parts).

5. See generally Joseph William Singer, Property and Social Relations: From Title to Entitlement, in Property and Values: Alternatives to Public And Private Ownership 3 (Charles Geisler \& Gail Daneker eds., 20oo) [hereinafter Singer, Property and Social Relations]; Joseph William 
"relational contract" 6 and, in particular, their emphasis on the determinative role of social relations in the construction of property and contract rights. The bundle of sticks metaphor is at the heart of relational property because it recognizes that property rights can be, and often are, disaggregated as they adapt to changing social, economic, and technological demands. As we will show in the context of the reform of Chinese rural land, the combination of the metaphor of separable interests-the sticks in the bundle-and the dependence of property interests on social relationships can explain the evolution of property rights more accurately than a perspective that stresses a single central meaning of property.

The core of our argument is simple: it is analytically more accurate to define each stakeholder's specific interests in rural land than to answer the question of legal title. Identifying the distinct powers of developing and transferring rural land, for example, tells us more about control of the land than the right to exclude. What's more important, when property law lags behind property relations, the latter will prevail and shape the eventual allocation of economic, social, and political powers. It is the social relations of particular villages in similar or identical institutional structures that determine their future development. Different villages make different and even opposite property arrangements. The normative implication is that relational property can function without property law, but property law cannot function without embedding itself in social relations.

The rest of this Essay is structured as follows: Part II criticizes the in rem view of the evolution of property rights. Part III develops the concept of relational property and evaluates its compatibility with the bottom-up evolution of property rights. Part IV utilizes the concept of relational property to analyze Chinese rural land reform. Part V concludes.

\section{IN REM Property AND the EVOLUtion OF Property Rights}

Who is eligible to serve as an owner of property? Individual persons, close-knit communities, and governments "all can and do own property." 7 But what do property rights mean? Some scholars believe that property is a bundle of rights and indicates which of the designated individuals is entitled to engage in which uses of particular resources. ${ }^{8}$ This in personam approach defines property as social relations between persons with respect to resources

Singer, The Reliance Interest in Property, 40 STAN. L. REV. 611 (1988) [hereinafter Singer, The Reliance Interest in Property].

6. See generally Ian R. Macneil, Contracts: Adjustment of Long-Term Economic Relations Under Classical, Neoclassical, and Relational Contract Law, 72 NW. U. L. REV. 854 (1978) [hereinafter Macneil, Contracts]; Ian R. Macneil, Relational Contract: What We Do and Do Not Know, 1985 WIS. L. REV. $4{ }^{8} 3$; Ian R. Macneil, Relational Contract Theory: Challenges and Queries, 94 NW. U. L. REV. 877 (2000).

7. Thomas W. Merrill \& Henry E. SMith, The OXFord INTRODUCTIONS to U.S. LAW: PROPERTY 3 (2010).

8. Id. at $4-5$. 
and is analogized to a bundle of rights. Another school of thought holds that "property is a distinctive type of right to a thing, good against the world." 9 This in rem concept of property consists of two parts. The first part is the emphasis on "property as the law of things." ${ }^{10}$ As Henry E. Smith argues, "the definition of a thing and its role in mediating private interactions lie at the heart of property." "11 The "thing" plays a role in depersonalizing and formalizing property relations. ${ }^{12}$ In general, this in rem concept views property as the relationship between human beings and resources, instead of a web of social relations among human beings. "First, it identifies particular resources ('things'), and specifies which person (the 'owner') is to act as the gatekeeper or regulator of the thing." 13 Things are "modules" through which law can organize the complex relationships into "lumpy packages" of legal relations. ${ }^{14}$ This approach, according to Yun-chien Chang and Smith, presents a structured bundle of relationships that minimize information costs. ${ }^{15}$

The second part of this in rem theory of property is the emphasis on the right to exclude. The right to exclude others from some definite thing is central to what the owner owns. ${ }^{16}$ To describe someone as an owner of some thing is to say that such person has the right to exclude others' use of the thing. Thomas Merrill holds that the right to exclude is more than just one stick in the bundle of property rights. "Give someone the right to exclude others from a valued resource . . . and you give them property. Deny someone the exclusion right and they do not have property." ${ }_{17}$ But Smith recently argued that "the right to exclude ... is not quite a sine qua non" of property, and "the characteristic features of property ... can[not] be derived logically from ... the right to exclude." ${ }^{18}$ In the same essay, he addresses other property rights, such as the right to transfer and the right to use. Chang, also in a recent essay, writes that "ownership" is just one type of property right, and he labels the right to transfer and the right to use, among others, as

9. Thomas W. Merrill \& Henry E. Smith, Essay, What Happened to Property in Law and Economics?, 111 YALE L.J. $357,35^{8}$ (2001).

10. See generally Smith, supra note 4 (asserting that the characterization of property as a bundle of rights is flawed).

1 1. Henry E. Smith, The Thing About Exclusion, 3 Brigham-Kanner Prop. RTs. Conf. J. 95, $123(2014)$.

12. See generally id. (explaining that "[p] roperty is the law of things" and does not revolve around the right to exclude).

13. See Thomas W. Merrill \& Henry E. Smith, The Property/Contract Interface, 101 CoLum. L. REV. 773, 790 (2001).

14. Smith, supra note 4 , at 1693 .

15. See Yun-chien Chang \& Henry E. Smith, An Economic Analysis of Civil Versus Common Law Property, 88 Notre DAme L. ReV. 1, 3-5 (2012); Yun-chien Chang, The Economy of Concept and Possession, in LAW AND ECONOMICS OF Possession 103, 108 (Yun-chien Chang ed., 2015).

16. Merrill \& Smith, supra note 9 , at 360 .

17. Thomas W. Merrill, Property and the Right to Exclude, 77 NEB. L. REV. 730, $73^{\circ}$ (1998).

18. Smith, supra note 11 , at 96,119 . 
"subsidiary rights." 19 Despite these recent elaborations, however, the in rem concept retains its long-time emphasis on the right to exclude as the natural consequence of defining property as law of things. Under this view, the first question to ask remains who owns the thing, which generally means who is the gatekeeper and has exclusive control over the thing.

Merrill and Smith argue that legal realists and legal economists have successfully replaced the traditional in rem concept of property rights with the bundle of rights picture. ${ }^{20}$ According to them, someone who believes that property is a right to a thing suffers from a lack of sophistication. ${ }^{21}$ Nonetheless, the Blackstonian concept of absolute dominion still dominates our imagination of property rights and legal discourse. The standard trilogy of private, communal, and state property rights presumes the in rem concept of property rights and is evidence of the Blackstonian concept. "Theorists push reforms towards one type or the other, but none" has substantially challenged the trilogy itself. ${ }^{22}$

Private property, despite the inherent ambiguity of its boundaries, is the benchmark and starting point of this trilogy. Sir William Blackstone defines private property as a man's "sole and despotic dominion . . . over the external things of the world." ${ }^{23}$ His is undoubtedly an in rem portrayal of property rights. Further, "comm[unal] property designates resources that are owned or controlled by a finite number of people who manage the resource together and exclude outsiders." ${ }_{4}$ Essentially, it is "a regime that holds some resources as a commons among a group of 'insiders,' but as an exclusive right against 'outsiders." ${ }_{25}$ It is "commons on the inside, [private] property on the outside." ${ }^{6}$ State property, or centralized property, means that the state holds all rights of exclusion and is the sole locus of decision-making regarding the use of resources. ${ }^{27}$ Like the definition of private property, both communal and state property present a relationship between a thing and an owner, in which exclusion is the core.

This in rem property rights theory also dominates the evolution of property rights literature. The majority of existing research, following the path-breaking work of Harold Demsetz, focuses on the paradigmatic situation in which the evolutionary process starts with open-access or communal

19. Chang, supra note 15 , at 5 .

20. Merrill \& Smith, supra note 9 , at $35^{8-59}$.

21. Id. at $357-5^{8}$.

22. Michael A. Heller, The Dynamic Analytics of Property Law, 2 THEORETICAL INQ. L. 79, 82 (2001).

23. 2 William Blackstone, COMMENTARIES *2.

24. Hanoch Dagan \& Michael A. Heller, The Liberal Commons, 110 YALE L.J. 549, 557 (2001).

25. Carol M. Rose, The Several Futures of Property: Of Cyberspace and Folk Tales, Emission Trades and Ecosystems, 83 MINN. L. REV. 129,155 (1998).

26. Dagan \& Heller, supra note 24, at 557 (quoting Rose, supra note 25, at 155 ) (alteration in original).

27. Heller, supra note 22, at $8_{5}$. 
property and ends with private individualized property. Demsetz discussed the emergence of private property among Indians of the Labrador Peninsula in his 1967 article..$^{28}$ Robert Ellickson explored the switch from group ownership to individual ownership using various empirical materials. ${ }^{29}$ Michael Heller investigates the post-communist transitions of property regimes in Russia, which aims at the transformation from government ownership to private ownership. $3^{\circ}$ Other scholars, such as Terry Anderson, P.J. Hill, D. Bruce Johnsen, John Umbeck, and Barry Field, enriched the theory of property rights in different respects, but they generally did not go beyond the movement from open-access or communal property to individualized private property. ${ }^{11}$ A few works discuss evolution in the reverse direction, $3^{2}$ but overall the contemporary literature on the evolution of in rem property rights remains incomplete in three important ways.

First, the concept of exclusion is ambiguous and varies with social, institutional, and technological contexts. To cite an illustrative example, in one author's home village in rural China, whenever the door is open, villagers are free to enter into a neighbor's home and even stay there for a while to wait for the owner to return. In contrast, in the other author's Manhattan neighborhood, entrance without permission would lead, at least, to an immediate 911 call. This contrast is an example, however unscientific, of how the specific meaning and the extent of the right to exclude will vary with circumstance.

And circumstance is not limited to the nature of the relevant community norms but extends to institutional and technological settings. Amy Kapczynski and Talha Syed iconized the term "the continuum of excludability" in discussing the limits of patents. 33 They argue that "excludability is not a binary quality, either 'on' or 'off' depending on the availability or absence of

28. See generally Harold Demsetz, Toward a Theory of Property Rights, 57 AM. ECON. REV. 347, $35^{\mathrm{O}-5} 5^{2}(1967)$.

29. See generally Ellickson, supra note 2.

3o. See generally Michael A. Heller, The Tragedy of the Anticommons: Property in the Transition from Marx to Markets, 111 HARV. L. Rev. 621 (1998).

31. See generally Terry L. Anderson \& P.J. Hill, The Evolution of Property Rights: A Study of the American West, 18 J.L. \& ECON. 163 (1975); Barry C. Field, The Evolution of Property Rights, 42 KyKLOS 319 (1989); D. Bruce Johnsen, The Formation and Protection of Property Rights Among the Southern Kwakiutl Indians, 15 J. LegAL STUD. 41 (1986); John Umbeck, The California Gold Rush: A Study of Emerging Property Rights, ${ }_{4} 4$ EXPLORATIONS ECON. HIST. 197 (1977).

32. See, e.g., Abraham Bell \& Gideon Parchomovsky, The Evolution of Private and Open Access Property, 1o THEORETICAL INQUIRIES L. 77 (2009) (discussing forces that motivate the shift from private ownership to open access); David D. Haddock \& Lynne Kiesling, The Black Death and Property Rights, $3^{1}$ J. LEGAL STUD. S $_{545}$ (2002) (discussing how the plague impacted feudal property institutions); Henry E. Smith, Exclusion Versus Governance: Two Strategies for Delineating Property Rights, 31 J. LEGAL STUD. $\mathrm{S}_{453}$ (2002) (discussing the emergence of the open-field system from the earlier rough individual tenure).

33. See generally Amy Kapczynski \& Talha Syed, The Continuum of Excludability and the Limits of Patents, 122 YALE L.J. 1900 (2013). 
property rights." 34 They continue: "Rather, it is highly variable across information goods, and is affected not only by formal legal entitlements, but also by existing technologies[,] ... existing social norms[,] . . . and the existing institutions ...."35 Recognizing the continuum of excludability expands the traditional view of information goods based on a rigid view of exclusion and applies not only to intellectual property, but also to property theory in general. Given the diversity of legal systems, unequal accesses to technologies, decentralized social norms, and different institutional environments, as well as different properties of different resources, the excludability of resources varies across the spectrum from ideal private property to open access. By identifying institutions and social norms as key determinants of excludability, Kapczynski and Syed have focused on the social relations of information goods rather than on the relationship between information goods and their owners..$^{6}$ The embedded picture of property rights in their discussion is in personam rather than in rem.

The standard property trilogy, which uses the right to exclude as one criterion, has also been criticized by Heller and Hanoch Dagan. According to Dagan and Heller, this familiar conceptual map has limited debate in three distinct ways: (1) "the categorization is incomplete," oversimplified, and should include new categories of property, such as anticommons 37 and semicommons $; 3^{8}(2)$ the existing categories, such as private property, may themselves be renegotiated and a richer, alternative conception developed; and (3) it is also possible to synthesize features of existing property types to create vigorous hybrids, such as the liberal commons.39 Their concept of the liberal commons focuses on the crucial goals of social relations-individual autonomy, interpersonal cooperation, and community prosperity $4^{\circ}$ —rather than the relationship between the resources and their owners.

Second, the in rem concept of property rights overemphasizes the right to exclude and falls short of explaining the change of other sticks in the bundle of rights. As a result, another trend of the evolution of property rights has been ignored in the mainstream law and economics. Following are several examples.

34. Id. at 1903; compare id., with Henry E. Smith, Property and Property Rules, 79 N.Y.U. L. REv. 1719,1755 (2004) ("In an exclusion strategy, the law sets up rough signals (informational variables, proxies) defining the boundaries of the asset. Within this zone of protection, owners have the choice of how to invest in or consume the asset.").

35. Kapczynski \& Syed, supra note 33 , at 1903 .

36. Id.

37. Dagan \& Heller, supra note 24, at $55^{8}$ (citing Heller, supra note 30 , at 622-26).

38. See generally Henry E. Smith, Semicommon Property Rights and Scattering in the Open Fields, 29 J. LEGAL STUD. 131 (2000).

39. See generally Dagan \& Heller, supra note 24.

4o. Id. at 574 . 
Morton Horwitz documents the transformation in the conception of property in the 19th century and argues that the Blackstonian concept of ownership necessarily circumscribed the rights of others to develop their land. $4^{1}$ As he writes:

[A]s the spirit of economic development began to take hold of American society in the early years of the nineteenth century, however, the idea of property underwent a fundamental transformation-from a static agrarian conception entitling an owner to undisturbed enjoyment, to a dynamic, instrumental, and more abstract view of property that emphasized the newly paramount virtues of productive use and development. $4^{2}$

Claire Priest investigates "an issue central to the economic and political development of the early United States: laws protecting real property from the claims of creditors." 43 Traditional English law protected inheritance "by protecting real property from the claims of creditors in multiple ways." 44 "The legal restrictions on creditors' ability to seize land in satisfaction of debts helped to stabilize the landed class by protecting real-property holdings from the risk associated with accumulated unsecured debt." 45 Priest shows that: "[T] he status of the American colonies . . . in the British Empire, [which was] distinguishable socially and politically from England, and the desire among English creditors and colonial subjects to improve credit conditions in the Empire led to the removal ... of traditional English protections to land from creditors." 46

It is a story in which, alienability, rather than the right to exclude, is the focus, but nobody would deny that it is an issue essential to the property system. Furthermore, Priest highlights the social, economic, and political contexts in the evolution of property rights:

English law reflected a society in which political and social authority was vested in a landed class that perpetuated itself through longterm ownership of real property. . . Americans from the founding era forward, however, viewed the greater circulation of land in America as the basis of a new political ideal-republicanism-that offered more opportunity for political participation than existed in European society. 47

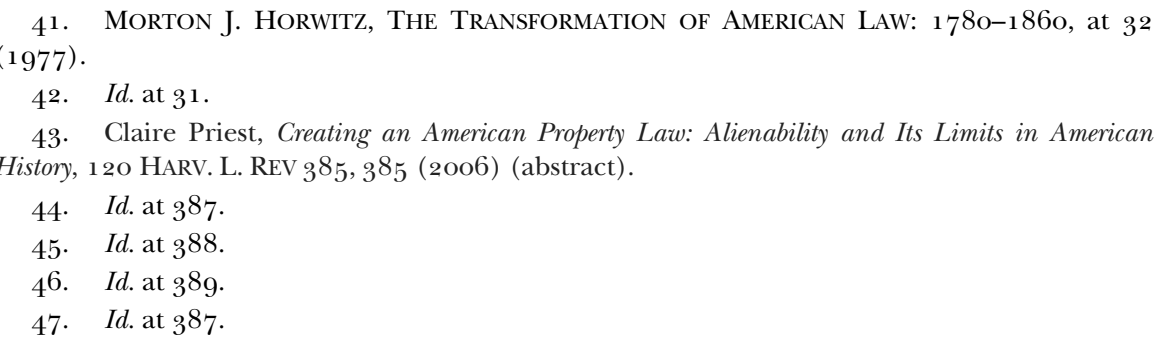


In short, the transformation of the American property law resulted from the transformation of the economic, political, and social relations. $4^{8}$

The same can be said of Steven Kochevar's investigation of the rise of institutional mortgage lending in early 19th-century New Haven, Connecticut. ${ }^{49}$ His research also reveals the crucial role of political and social relations in the evolution of property rights. $5^{\circ}$ Specifically, his research documents key differences between the elite mortgages made before 1837 , i.e., "capital allocation that relies on pre-existing social networks," and the later mortgages made by the Town and the Savings Bank, i.e., "capital allocation that does not depend on pre-existing social networks." ${ }_{51}$ "By creating a political forum where economic actors who were not plugged into pre-existing elite social networks could present and assemble privately held knowledge in a public setting, the Town performed an informationaggregating service [to facilitate institutional mortgage lending]." ${ }^{2}$

Third, Merrill and Smith develop the optimal standardization thesis and further the numerus clausus principle based on the in rem concept of property rights, which on the whole, overemphasizes the role of law and downplays the role of social norms in the evolution of property rights. 53 For them, the unique advantage of in rem rights is that they conserve information costs relative to in personam rights. This is especially true "in situations where the number of potential claimants to resources is large, and the resource in question can be defined at relatively low cost." 54 Merrill and Smith argue that:

In rem rights offer standardized packages of negative duties of abstention that apply automatically to all persons in the society when they encounter resources that are marked in the conventional manner as being "owned." Information is conserved by making these duties apply automatically to delineated resources without regard to the identity of the owner; by making the duties uniform; by restricting the duties to a short list of negative obligations, easily defined and understood by all; and by marking boundaries using easily observed proxies. 55

In short, property rights exist in a fixed number of forms. $5^{6}$ Borrowing from civil law countries, Merrill and Smith call the principle that property rights

48. Id. at 390 .

49. See generally Steven J. Kochevar, Note, The Rise of Institutional Mortgage Lending in Early Nineteenth-Century New Haven, 124 YALE L.J. $15^{8}$ (2014).

$5^{\text {o. }} \quad I d$. at 162 .

51. $\quad I d$. at 163 .

52. Id. at 199 .

53. Thomas W. Merrill \& Henry E. Smith, Optimal Standardization in the Law of Property: The Numerus Clausus Principle, 110 YALE L.J. 1, $3^{8-40}$ (2000).

54. Merrill \& Smith, supra note 13 , at 793 .

55. Id. at 794 .

56. Merrill \& Smith, supra note 54 , at $3-4$. 
must conform to certain standardized forms numerus clausus-which, in Latin, means the number is closed-which "functions to promote the optimal standardization of property rights." 57

In the world of numerus clausus, law is the main source of property rights. Merrill and Smith argue that the government, and particularly the legislature, should play a role in standardizing rights. $5^{8}$ This actually aligns closely to Bentham's argument that without law there would be no rights.59 Smith has made a famous analogy between language and property. He explicitly states that the grammar of a language is standardized spontaneously, while the source of the standardization of property rights is different. ${ }^{60}$ In a recent paper, Smith presents a systematic modular theory of in rem property rights in which the embedded legal centralism is also apparent. ${ }^{61}$ His modular theory presupposes a state that defines the modules and when remodularization is necessary for major change, "in our legal system this type of change is typically channeled to legislatures." ${ }^{2}$ In this Symposium, Chang and Smith distinguish between the strict form of the numerus clausus principle, under which only the legislature can create new property forms, and a broader version of the numerus clausus principle, in which they hypothesize that property customs that create new property forms and yet impose tolerable information costs are more likely to be recognized by courts. ${ }^{63}$

Maybe this hypothesis should be qualified by assuming that everything else is equal. Information cost is important, but it is only one of the many factors that contribute to the evolution of property rights. Whether courts, legislatures, or even the executive branch is more capable of designing property rights is very sensitive to context. More generally, it is also doubtful whether law is always the main engine for property reform. For example, the incapacity of property law systems in developing countries has resulted in the prevalence of informal property rights that do not come from the formal law. ${ }^{64}$ In contrast to the standardized picture of in rem property, informality

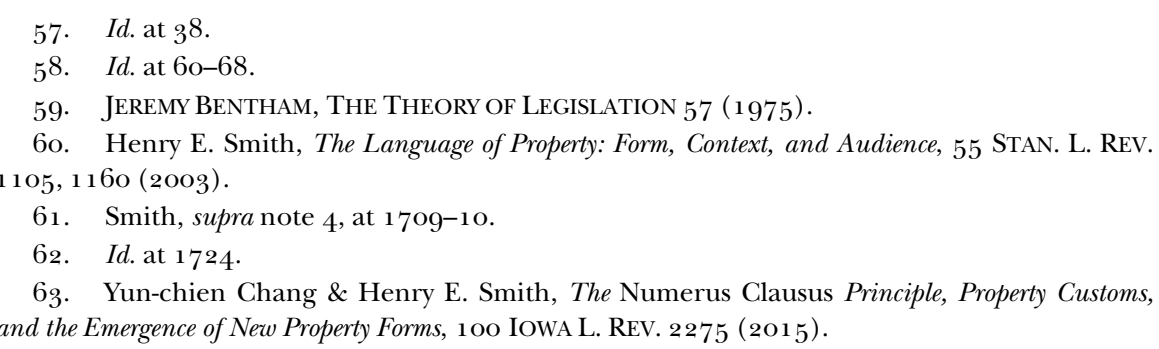

64. See, e.g., Hernando DE Soto, The Mystery of CaPital: Why CaPitalism Triumphs in THE WeSt AND FAils Everywhere ElSE 166-68 (2000); Hernando de Soto, The Other Path: The ECONOMIC ANSWER TO TERrorism 19-26 (1989); Shitong Qiao, Planting Houses in Shenzhen: A Real Estate Market Without Legal Titles, 29 CAN. J.L. \& SoC'Y 253, 270-71 (2014) [hereinafter Qiao, Planting Houses]; Shitong Qiao, Small Property, Big Market: A Focal Point Explanation, 63 AM. J. Comp. L. (forthcoming 2015) [hereinafter Qiao, Small Property], available at http://papers. ssrn.com/sol3/papers.cfm?abstract_id=2399675; Leah M. Trzcinski \& Frank K. Upham, Creating Law from the Ground Up: Land Law in Post-Conflict Cambodia, 1 ASIAN J.L. \& SoC'Y 55 (2014). 
is a widely acknowledged symptom of property rights in developing countries. The variety of power structures and social relations has made property rights quite a chaotic and irregular system in many developing countries. ${ }^{6}$ The World Bank and other international organizations have devoted a lot of time and resources to formalizing these informal property systems but have not made substantial progress. ${ }^{66}$ The failure of legal titling programs in some countries, and also the uncertain effects of legal titling on promoting investment and economic development, have led to reflections on private property as a development strategy. ${ }^{6} 7$ Based on our previous review of the in rem basis of the existing property debate, this kind of opinion is not at all surprising, but neither is it helpful. Going beyond the trilogy of property debates requires us to not take the failure of one of the property forms as a reason for another property form to succeed. Instead, we should shift from choosing a relationship between resources and the owners to investigating the social relations with respect to the resources.

\section{RELATIONAL Property AND BotTom-UP INSTITUTIONAL EVOLUTION}

\section{A. RELATIONAL PROPERTY}

Borrowing from Joseph Singer's "property rights as social relations" and Ian Macneil's "relational contract," we develop the concept of "relational property" and argue that it is the basis of spontaneous order. ${ }^{68}$ The emphasis on social relations is far from rare in the field. For example, Carol Rose also argues "that property on the one hand, and the regulation of property on the other, are aligned in a set of overlapping evolutionary relationships." 69

The relational property theory presents that property rights are a web of mutually dependent relationships. $7^{\circ}$ Property rights are defined "in terms of human relationships rather than relations between persons and things." ${ }^{11}$ It also aligns with " $[\mathrm{t}]$ he legal realists view that shifts attention from relations between people and things to relations among people with respect to the valued resource." $7^{2}$ According to the theory, rights emerge from the understandings that come from relationships between people that develop

65. See Daniel Fitzpatrick, Evolution and Chaos in Property Rights Systems: The Third World Tragedy of Contested Access, 115 YALE L.J. 996, $1011-16$ (2006).

66. See Tor Krever, The Legal Turn in Late Development Theory: The Rule of Law and the World Bank's Development Model, $5^{2}$ HARV. INT'L L.J. 287, 304-O7 (2011). See generally Trzcinski \& Upham, supra note 64 .

67. Trzcinski \& Upham, supra note 64.

68. See generally Singer, Property and Social Relations, supra note 5; Macneil, Contracts, supra note 6.

69. Carol M. Rose, Property Rights, Regulatory Regimes and the New Takings Jurisprudence-An Evolutionary Approach 57 TENN. L. REV. 577, 577-78 (1990).

7o. Singer, The Reliance Interest in Property, supra note 5, at $6_{5} 2$.

71. Singer, Property and Social Relations, supra note 5, at 8.

72. Id. 
over time rather than rights being articulated and clear under the law.73 "[P] roperty does not have a static definition but rather reflects [everchanging] relationships between" the government, the local community, and individuals over time. 74 Therefore, under the theory, "[u]nderstanding the evolution of property rights requires an examination of the" historical and social contexts of human relationships with regard to property. 75

The bundle-of-sticks metaphor is at the heart of this relational property theory. It highlights the legal realists' recognition "that property rights can be and often are disaggregated." $7^{6}$ We can often observe the subtle and incremental adjustment and evolution of property rights, as well as the moments of rapid fundamental change in property systems. We can observe not only the shift of the right to exclude from one person to another, but also the evolution of the rights to use and transfer. Relational property accommodates the more nuanced and incremental changes in property rights, and it provides a platform for different stakeholders to engage and bargain with each other in the evolution of property rights, which can avoid or lessen the direct confrontation and conflicts in the contest for exclusive control over the piece of property. Relational property theory also contemplates the right to exclude, but it is more the right to exclude others from interfering with the exercise of that particular right, rather than the right to exclude others from the thing in total. 77 The most important implication of the bundle-of-rights metaphor is that it shifts our attention from asking who owns the property to understanding who has what rights to the property and to examining the social relationships around a piece of property that is "beset by conflicting values and competing interests." 78

We agree with Singer and others on the important and determining role of social relations in the construction of property rights, but do not necessarily agree with the way they characterize social relationships. For example, we agree with Singer that there is a basic connectedness between people, but we would temper its centrality with a recognition that autonomy is an essential dimension of personhood.79 Moreover, different social control systems follow different logics, and we should not mix them, in particular, the social and legal relations. Singer criticizes what he calls "[t] he free market model" in

73. See id.; Singer, The Reliance Interest in Property, supra note 5, at 618-23; Joseph William Singer \& Jack M. Beermann, The Social Origins of Property, 6 CAN. J.L. \& JURISPRUdENCE 217,218 (1993).

74. Wendell E. Pritchett, The "Public Menace" of Blight: Urban Renewal and the Private Uses of Eminent Domain, 21 YAle L. \& POL'Y REV. 1, 6 (2003).

75. Id. For examples of such examinations, see generally Rose, supra note 69; Joseph L. Sax, Lecture, Some Thoughts on the Decline of Private Property, $5^{8}$ WASH L. REV. 481 (1983); and Laura S. Underkuffler, On Property: An Essay, 1 oo YALE L.J. 127 (1990).

76. Singer, Property and Social Relations, supra note 5, at 8.

77. See id.

78. $I d$.

79. See id. 
which "rights are clearly defined at decision points" and individuals are "connected to each other legally in only two ways: through the universal community of the state or through private agreements." 80 Though we agree with him that we should take fluid relationships into consideration, we disagree with him about the implications. Our focus is not to establish legal rights and obligations directly from social relationships, as in Singer's analysis of the U.S. Steel Company case; ${ }^{81}$ rather, we are more interested in the mechanism of social change and how it leads to systematic legal change.

Relational property also shares characteristics with Ian Macneil's relational contract. Macneil argued that relational contract would be a solution to the "constant clash . . . between the need for stability and the need to respond to change" in the area of contracts. ${ }^{82} \mathrm{He}$ argues that:

In the neoclassical system, the reference point for those questions about the change tends to be the original agreement. In a truly relational approach the reference point is the entire relation as it had developed to the time of the change in question (and in many instances as it has developed since the change). This may or may not include an 'original agreement;' and if it does, may or may not result in great deference being given it. ${ }^{83}$

Deference to social relations rather than original contract can resolve the conflict between change and stability. This logic also applies to the field of property. In the law and economics tradition, scholars tend to use the legal system as the reference point of property rights. This reference point, however, results in a conundrum: economic development requires both secure property rights and the ability to reallocate property in response to social changes. Following this logic, we must ask: how can property rights be adjusted and still be considered secure ${ }^{84}$ Echoing Macneil's insights, this Essay views relational property as a solution to the conundrum of stability and change in property. In the relational property approach, the reference point is the ongoing relations, rather than the original law. ${ }^{85}$ In other words, it is the social relationships that decide the arrangement of property rights.

This is the difference between relational property and in rem property. As Chang and Smith show in this Symposium and elsewhere, the $i$ property theory repeatedly recognizes the existence of social relations. ${ }^{86}$ Nevertheless,

\footnotetext{
8o. Singer, The Reliance Interest in Property, supra note 5, at $65^{2-53}$.

81. See id. at 614-20.

82. Macneil, Contracts, supra note 6 , at 854 .

83. $\quad I d$. at 890 .

84. See generally Naomi R. Lamoreaux, The Mystery of Property Rights: A U.S. Perspective, 71 J. ECON. HIST. 275 (2011) (asking the same question).

85. Macneil, Contracts, supra note 6, at 890.

86. See generally Chang \& Smith, supra note ${ }_{15}$; Chang \& Smith, supra note 63; Henry E. Smith, Community and Custom in Property, 10 THEORETICAL INQUIRIES L. 5 (2009); Henry E. Smith, Custom in American Property Law: A Vanishing Act, $4^{8}$ TEX. INT'L L.J. $5^{\mathrm{O}} 7$ (2013).
} 
under the in rem property theory, social relations only play a background role, and property customs are marginal, assuming that countries will legalize these customs eventually. In contrast, the relational property theory recognizes that social relationships are the primary rather than supplementary sources of property rights. Relational property can function without property law, but property law cannot function without embedding itself in social relations.

\section{B. BOTTOM-UP INSTITUTIONAL EVOLUTION}

Merrill and Smith argue that "the legal realists who promoted the bundleof-rights metaphor had a political agenda, namely, dethroning the sanctity of private property and the private ordering it enables in order to enhance levels of collective control and redistribution." 87 Merrill and Smith worry that the ability to adjust property rights "along countless margins" carries the implication that these rights no longer run between only the individual owner and the rest of the world but instead run between the individual and the allpowerful state. ${ }^{88}$

We suggest that the in personam portrayal of property rights does not necessarily encourage state intervention, but, on the contrary, that it can encourage bottom-up institutional evolution. ${ }^{89}$ There is suspicion of the "bundle of rights" concept because "a 'bundle,' which, whether one speaks of cloths, rags, or property rights, looks like some arbitrary assemblage with no inner coherence, kept together only because someone ties them together like stalks of wheat. ... [T] he fear is that the people who put the bundle together are public authorities." $9^{\circ}$ As Richard Epstein has written, it is important to differentiate between "the bundle-of-rights terminology" and "the question of whether we think of property rights from a top-down or bottom-up perspective," which is ultimately a political choice. ${ }^{91}$ There is nothing in the bundle-of-rights conception that makes it more amenable to the top-down approach. Rather, because it keeps the freedom of individual choice, it can be more consistent with the bottom-up approach. According to Epstein, " $[\mathrm{s}] \mathrm{o}$ long as we know how the rights were separated and how they could be reassembled, we can let the parties decide how they choose to interact among themselves and with the outside world." $9^{2}$ Or as Singer and others have said, "the crucial question is not just the rights of the individual owner vis-à-vis the

87. Robert C. Ellickson, Two Cheers for the Bundle of Sticks Metaphor, Three Cheers for Merrill and Smith, 8 ECONJ. WATCH 215, 216 (2011) (internal quotation marks omitted) (citing Thomas W. Merrill \& Henry E. Smith, Making Coasean Property More Coasean, 54J.L. \& ECON. S77, S83 (2011)).

88. Merrill \& Smith, supra note 87 , at $\mathrm{S} 82$.

89. See generally Richard A. Epstein, Bundle-of-Rights Theory as a Bulwark Against Statist Conceptions of Private Property, 8 ECONJ. WATCH 223 (2011).

9o. Id. at 225 .

91. Id. at 227.

92. Id. at 233 . 
state but the right relationships that must be established between that owner and others in the community." 93

An important question is whether justifications for a centralized property system are persuasive enough to sacrifice institutional diversity as well as individual and communal autonomy. According to James Scott, ancient emperors always wanted comprehensive information about their subjects' properties so that they could collect taxes easily. 94 To achieve this clarity, they were willing to sacrifice the complexity and diversity of their empires.95 Thus, the in rem property theory and the numerus clausus principle might have been adopted by civil law countries not to reduce information costs, but simply to ease the emperors' rule. As Merrill and Smith would agree, institutional comparison "must be sensitive to context." ${ }^{6}$ It might be better to leave the construction of property rights to the existing specific social relations.

\section{From CLOSE-KNIT COMmUNity to UNBounded NETWORK OF SOCIAL RELATIONS}

A fundamental issue with relational property, however, is the constitutive role of social norms: are these norms limited to close-knit communities and, therefore, incapable of serving as the basis of a society? Robert Ellickson's pioneer work launched the law and social norms movement in the legal academy. Both of his books-Order Without Law: How Neighbors Settle Disputes and the more recent The Household: Informal Order Around the Hearth-are about property rights relations in close-knit communities.97 He also qualifies his order-without-law thesis within close-knit communities, $9^{8}$ leaving open the question whether social norms can arise in contexts with more anonymous subjects or fewer repeat players, including what Lior Strahilevitz calls "looseknit groups" and "intermediate-knit groups." 99 Regarding the conventional wisdom that a well-functioning property law system is the foundation of the economy and society, it is important to ask whether society-wide property

93. Joseph William Singer, The Ownership Society and Takings of Property: Castles, Investments, and Just Obligations, 30 HARV. ENVTL. L. REV. 3o9, 331 (2006) (citing Laura S. Underkuffler, Tahoe's Requiem: The Death of the Scalian View of Property and Justice, 21 CONST. COMMENT. 727, 751 (2004)).

94. James C. SCOTT, SEeing Like a State: How Certain SCHEMES to Improve The Human CONDITION HAVE FAILED 23 (1998).

95. $I d$.

96. Merrill \& Smith, supra note 53, at 68.

97. See generally Robert C. Ellickson, ORDER Without LAW: HOW NeighbORS SETTLE DisPutes (1991) [hereinafter Ellickson, ORDER Without LAW]; ROBERT C. EllickSON, THE HOUSEHOLD: INFORMAL ORDER AROUND THE HEARTH (2008) [hereinafter ElLICKSON, THE HOUSEHOLD].

98. Compare ElLICKSON, ORDER Without LAW, supra note 97, at 123 (explaining the theory of informal norms that achieve order without law), with ELLICKSON, THE HOUSEHOLD, supra note 97, at 92 (showing household relationships provide order without external legal rules).

99. Lior Jacob Strahilevitz, Social Norms from Close-Knit Groups to Loose-Knit Groups, 7 o U. CHI. L. REV. 359, 360 (2003). 
norms can arise. ${ }^{100}$ Based on social network theory, we argue that property rights can arise in an unbounded network of social relations.

An important discovery of social network theory is that most human social networks are scale free. ${ }^{101}$ There are numerous close-knit communities in the world, but they are not isolated; rather, they are connected to each other. ${ }^{102}$ Two theories have proven this.

The first is called the six degrees of separation, which means that everyone and everything is six or fewer steps away, by way of introduction, from any other person in the world, so that a chain of "a friend of a friend" statements can be made to connect any two people in a maximum of six steps. ${ }^{103}$ Supportive facts include "that the actor Kevin Bacon could be connected to virtually all of the roughly half a million people who had acted in feature films since 1898 ." ${ }^{104}$ As Strahilevitz comments, "[T] here are people who stay in touch with old friends, throw dinner parties, play matchmaker, and, most importantly, have close friends in a variety of different cliques. These are the Kevin Bacons of the world: society's supernodes." ${ }^{105}$

The second one is what Granovetter calls "the strength of weak ties." ${ }^{106}$ As he writes, "What makes cultural diffusion possible, then, is the fact that small cohesive groups who are liable to share a culture are not so cohesive that they are entirely closed; rather, ideas may penetrate from other such groups via the connecting medium of weak ties." ${ }^{107}$ "Weak ties serve a 'bridging' function, transferring new information from one closely knit group to another." 108

Such theories remind us of the possibility that social relations can be built beyond close-knit communities. In fact, social network analysis has been widely applied in the social sciences, and is based on the relationships among interacting units. ${ }^{109}$ "The fundamental difference between a social network explanation and a non-network explanation of a process is the inclusion of

10o. See Lior Jacob Strahilevitz, Charismatic Code, Social Norms, and the Emergence of Cooperation on the File-Swapping Networks, 89 VA. L. REV. 505, 508 (2003); Lior Jacob Strahilevitz, How Changes in Property Regimes Influence Social Norms: Commodifying California's Carpool Lanes, 75 IND. L.J. 1231 , 1232 (2000).

101. Lior Jacob Strahilevitz, A Social Networks Theory of Privacy, 72 U. CHI. L. REV. 919, 947-53 $(2005)$.

102. Id. at $95^{8 .}$

103. See, e.g., Strahilevitz, supra note 101, at 949. See generally John GuARE, Six DegreEs OF SEPARATiOn: A Play (1990).

104. Strahilevitz, supra note 101, at 949 .

105. Id. at $95^{1 .}$

106. Id. at 954. See generally Mark Granovetter, The Strength of Weak Ties: A Network Theory Revisited, 1 SOC. THEORY 201 (1983).

107. Id. at $95^{6}$ (quoting Granovetter, supra note 106 , at $215^{-16}$ ).

108. Id. at 955 (quoting Gabriel Weimann, The Strength of Weak Conversational Ties in the Flow of Information and Influence, 5 SOC. NETWORKS, 245, 246 (1983)).

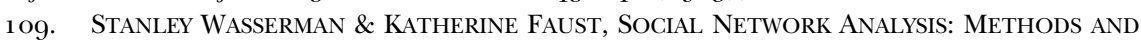
APPLICATIONS 4 (1994). 
concepts and information on relationships among units in a study." ${ }_{110} \mathrm{~A}$ network approach examines how members influence each other in order to make a decision by looking at interactions among network members. ${ }^{111}$ "[R] elations defined by linkages among units are a fundamental component of network theories." ${ }^{112}$ In social network analysis, "[a]ctors and their actions are viewed as interdependent rather than independent units," and "[r] elational ties ... between actors are channels for transfer or "flow' of resources." ${ }_{113}$ These characteristics of social network theory make it align well with the relational property theory.

\section{Chinese Rural Land Reform: The Evolution of Property Relations}

We can develop four hypotheses from the relational property concept. First, it is easier to define the stakeholders' rights than it is to answer who owns the property. Second, besides the right to exclude, other sticks in the bundle of rights may also play a major role in the evolution of property rights. Third, since property rights are created and defined by social relations, when property law lags behind property relations, the latter prevails. Fourth, property rights are relational, rather than absolute and, thus, need to be defined by specific social relationships. Similar actors in the same institutional background might have opposite property arrangements. An examination of the reform of Chinese rural land will illustrate these four hypotheses.

\section{A. WHO OWNS CHINA's LAND?}

Who owns China's land? There is no short answer because the question is misleading. It assumes an exclusive relationship between land and either the state, communities, or individuals or private entities. This conventional view further holds private "sole and despotic dominion" over real estate as the benchmark for comparison. ${ }^{114}$ As a result, several phrases have been invented to depict developments in the Chinese property regime, such as quasi-private ownership ${ }^{115}$ and incomplete property rights. ${ }^{116}$ Chinese land reform, however, is not simply the transfer of exclusive control from the public to the private. This in rem picture of property rights is inconsistent with Chinese reality. Rather, the right approach is to examine how the bundle of rights to Chinese land has been rearranged in the past three decades.

\footnotetext{
110. Id. at 6 .

111. Id. at 7 .

112 . Id. at 4 .

113 . Id.

114. See 2 BLACKSTONE, supra note 23 , at $*_{2}$.

115. See, e.g., James Kai-sing Kung, Choice of Land Tenure in China: The Case of a County with Quasi-Private Property Rights, 5o ECON. Dev. \& Cultural Change 793 (2002).

116. See, e.g., Michael T. Bennett, Aashish Mehta \& Jintao Xu, Incomplete Property Rights, Exposure to Markets and the Provision of Environmental Services in China, 22 CHINA ECON. REv. 485 (2011).
} 
The current land regime in rural China is a tri-party model: (1) The collective exercises ownership; (2) individual households enjoy use rights; and (3) the government monopolizes the rural-urban land conversion, which is the primary way to transfer land. In this model, the right to exclude is hard to define, but the bundle of rights of each stakeholder can be defined.

\section{The Collective's Ownership}

Article 10 of the Chinese Constitution says that rural land is collectively owned except for that owned by the state. ${ }^{17}$ This stipulation is confirmed by Article 8 of the Land Administration Law ("LAL") and Article 59 of the Chinese Property Law. ${ }^{118}$ Both statutes designate the villagers' committee, the villagers' group, or corresponding collective economic organizations as the body empowered to exercise collective ownership and manage the collectively owned land. ${ }^{119}$ In Shenzhen and some other places, the form of collective economic organizations is the village co-op. ${ }^{120}$

The core of collective ownership is the right to contract rural land to individual households. Most of the time, the villagers' committee or villagers' group represents the collective in exercising ownership. Chinese farmers refer to both institutions as "the collective" to distinguish it from "the state."

\section{Farmers' Use Right to Rural Land}

In 1993, Article 8 of the Chinese Constitution recognized the Household Responsibility System ("HRS") as the basic rural property institution, ${ }^{121}$ which was subsequently confirmed by the 2002 Rural Land Contract Law ${ }^{122}$ and the

117. Xianfa [CONSTitution] art. 10 (2004) (China).

118. Property Law of the People's Republic of China (adopted by the National People's Congress of China, Mar. 16, 2007, effective Oct. 1, 2007) art. 59 (China) [hereinafter Property Law], available at http://www.npc.gov.cn/englishnpc/Law/2009-02/20/content_1471118.htm; Land Administration Law of the People's Republic of China (adopted by the National People's Congress Standing Committee, June 25, 1986, revised on December 29, 1988, Aug. 29, 1998, and Aug. 28, 2004) art. 8 (China) [hereinafter Land Administration Law], available at http:// www.npc.gov.cn/englishnpc/Law/2007-12/12/content_1383939.htm.

1 19. Article 10 of LAL says:

The land owned by the farmers' collective is by law owned by the farmers' collective of the village, and managed and administered by the village collective economic organization or the villagers' committee; what is already owned by more than two rural collective economic organizations of the farmers' collective is managed and administered by each of these rural collective economic organizations or the villagers' groups; what is already owned by the farmers' collective of the township is managed and administered by the rural collective economic organization of the township.

Land Administration Law, art. 10.

1 20. Qiao, Planting Houses, supra note 64, at 26o-61.

121. XIANFA art. 8 (2004) (China).

122. Law of the People's Republic of China on Land Contract in Rural Areas (adopted by the National People's Congress Standing Committee of China, Aug. 29, 2002, effective Aug. 29, 
2007 Chinese Property Law. ${ }^{123}$ HRS ensures that the collective should contract collectively owned land to individual households. Individual households as contractors of rural land are free to use the contracted land for agriculture. The contract term has been legally fixed at 30 years, ${ }^{124}$ which can be extended. There are comprehensive measures to protect rural households' contract rights. After contracting the land to individual households, the collective has little right to intervene in the farmers' use of the contracted land for agriculture. ${ }^{125}$ At the same time, there are a series of restrictions for households to transfer their use rights: (1) they have to get the agreement of the collective; (2) they cannot change the agricultural use of the land; and (3) members of the same collective enjoy priority in buying transferred rights to contracted land. ${ }^{126}$

Besides engaging in agricultural activities, farmers need shelter for their families. Each household of the collective is eligible for and can get one piece of rural residential land for free to build a house. ${ }^{127}$ Rural land is supposed to be used only by farmers for agricultural use and other daily operations. Article 63 of LAL explicitly prohibits alienation of rural land use rights for nonagricultural use. ${ }^{128}$ In particular, urban residents are not allowed to buy rural houses or rural residential plots. This prohibition has been resoundingly affirmed in various government ordinances. ${ }^{129}$

\section{State Monopoly on Rural-Urban Land Conversion}

Urban land is state owned, and rural land is collectively owned. This distinction between rural and urban land is fixed in Article 10 of the Chinese Constitution. ${ }^{130}$ Preservation of agricultural land is one of the Chinese land administration regime's most important goals. As a result, rural land can be

2002), art. 35 (China) [hereinafter Rural Land Contract Law], available at http://www.npc.gov. cn/englishnpc/Law/2007-12/o6/content_1382125.htm.

123. See Property Law, art. 124 .

124. See Land Administration Law, art. 14. In 2008, at the third plenary session of the 17 th central committee, the Chinese Communist Party adopted a decision that the contract term of rural land should be kept stable and unchanged for a long time, which was interpreted by many Chinese scholars as a signal to further strengthen the security of farmers' rights to land.

125. See Rural Land Contract Law, art. 1.

126. See id. art. 35,37 .

127. Land Administration Law, art. 62.

128. There is one exception to this prohibition: in the situation of bankruptcy and amalgamation, use right to rural land of enterprises can be transferred. This exception was designed to promote the development of township-and-village enterprises. See Land Administration Law, art. 63 .

129. See, e.g., Guowuyuan guanyu shenhua gaige yange tudi guanli de jueding [Decision of the State Council on Deepening Reform and Strengthening Land Administration], No. 28 (2004); Guowuyuan bangongting guanyu yange zhixing youguan nongcun jiti jianshe yongdi falv he zhengce de tongzhi [Notice of the Office of the State Council on Strictly Implementing Laws and Policies Relevant to Rural Collective Construction Land], No. 71 (2007).

130. XIANFA art. 10 (2004) (China). 
used only for agriculture and related purposes, including building residential houses, public facilities, public goods, and township-and-village enterprises.

Rural-urban land conversion can be legally achieved only through "requisition," roughly equivalent to eminent domain, by the state. Section I of Article 43 of the 2004 LAL states that "[a]1l units and individuals that need land for construction purposes shall, in accordance with law, apply for the use of State-owned land." ${ }_{131}$ This clause makes the private transfer of rural landuse rights for non-rural use legally impossible. Moreover, Section II of Article 43 reiterates that state-owned land in Section I includes both state-owned land and land that the state has requisitioned, which effectively means that rural land can be used for construction only after requisition. Although state requisition of rural land is legally limited to the public interest and constrained by procedural requirements, these restrictions have not been effective. Rapid and massive urbanization has meant that, in reality, these legal rules are either ignored or relaxed. For example, the requirement of public interest rarely precludes local governments in China from requisitioning rural land for industrial or commercial development. ${ }^{132}$

The government alienates the use rights to state-owned land in two ways: free allocation (in several limited situations) and sale, which together constitute the "primary market" for urban land-use rights. The initial and subsequent non-government holders of land-use rights may further transfer them within certain limits. These further land transactions constitute the "secondary market" for urban land-use rights.

\section{B. SMALL PROPERTY: A ONE-STICK EVOLUTION}

As shown above, a key issue for Chinese rural land reform is the right to develop and sell rural land for non-agricultural uses. It is just one (or maybe two, depending on how one defines a property right) stick of property rights, and it is not the right to exclude.

According to the Chinese Ministry of Land and Resources, by 2007 Chinese farmers had built over 6.6 billion square meters of houses in contravention of the legal prohibition on private rural land development and transfer. The result was a huge market for illegal housing. By way of comparison, in 2007 the total floor space of housing sold on the legal housing market was only 0.76 billion square meters. People in China call these illegal buildings "smallproperty houses" (xiaochanquan in Chinese) because their property rights are "smaller" (weaker) than those on the urban/legal housing

131. Land Administration Law, art. 43 .

132. See Shitong Qiao, Chinese Small Property: The Co-Evolution of Law and Social Norms ch. 1 (forthcoming May 2015) (unpublished J.S.D. dissertation, Yale University) (on file with author). Of course the similar American constitutional limitation of eminent domain to "public use" has been similarly broadly interpreted. See, e.g., Kelo v. City of New London, 125 S. Ct. 2655 (2005). 
market, which have "big" property rights protected by the government. ${ }^{133}$

Shenzhen, a city in the southern part of Southern China's Guangdong Province which is situated immediately north of Hong Kong, has been the literal and symbolic heart of the Chinese economic miracle. ${ }^{134}$

Shenzhen is the city with the highest ratio of small-property houses to total floor space, where small-property houses contribute $47.57 \%$ of total floor space, compared to $30 \%$ in Xi'An and $20 \%$ in Beijing. These illegal buildings, without legal titles and concentrated in 320 intra-city villages, host most of the 8 million migrant workers in Shenzhen and are the main livelihood of the more than 300,000 local villagers. ${ }^{135}$

The small-property market has resulted from the changing economic, political, and social relations between villagers, government agencies, and other related actors. In particular, a network of market participants has grown from actors with strong ties with each other to actors with weak ties, and from bounded to unbounded. The property arrangement that a villager or a group of villagers can and would make is determined by its unique position in the social network. The scope, content, and strength of this property arrangement also change over time as social conditions and relationships change.

This market symbolizes the evolution of land rights in China without serious conflicts among the government, the village community, and individual villagers. This is attributed to the relational property structure, which provides a platform for stakeholders to adjust their behavior to changing social relations.

\section{Social Relations (Not Law) Decide Property Rights}

In the early 1980s, Deng Xiaoping's "reform and opening up" ${ }^{136}$ policy proved that the communist prohibition on land alienation would not work in a market-oriented economy. This inadaptability was most acute in the urban area, where both urban construction and cooperation with foreign investors could benefit greatly from land development and transfer. As a result, in 1988, China amended both the Constitution and LAL, stating that use rights to both state-owned and collective-owned land could "be transferred according to law." ${ }^{137}$ On May 19, 1990, the State Council promulgated

\footnotetext{
133. Qiao, Small Property, supra note 64 (manuscript at 3-4) (footnotes omitted).

134. See, e.g., Howard W. French, Chinese Success Story Chokes on Its Own Growth, N.Y. TIMES (Dec. 19, 2006), http://www.nytimes.com/2006/12/19/world/asia/19shenzhen.html.

135. Qiao, Small Property, supra note 64 (manuscript at 4 ) (footnote omitted).

136. See e.g., David Wall, China's Economic Reform and Opening-Up Process: The Role of the Special Economic Zones, 11 DEV. POL'Y REV. 239, 243-6o (1993).

137. XIANFA art. 2 (1988) (China) (amending art. 1o).
} 
detailed rules governing the sales of urban land-use rights from the government and the transfer of those rights among land users. ${ }^{138}$

This urban land-use reform not only built the legal basis for China's urban real-estate market, but it also made land the most important source of revenue for Chinese local governments. Local governments requisition rural land at compensation equal to its agricultural value and sell the same land on

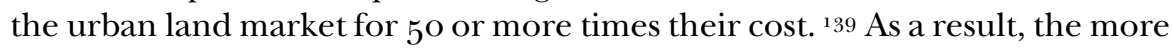
the urban real-estate market develops, the more unlikely that the central and local governments will liberalize rural land development and transfer. Even partial liberalization would jeopardize the governments' monopoly over land. ${ }^{14^{\circ}}$

Unsurprisingly, the Chinese government has never promulgated legal authorization for the transfer of rural land-use rights. Instead, in 1998, the Chinese government made a comprehensive revision to LAL that excluded the possibility to transfer rural land-use rights. The 1998 revision also made it clear that rural-urban land conversion can only be legally achieved through state requisition. ${ }^{14^{1}}$

Nevertheless, the evolution of social relations still leads to change in property rights. Legitimate organizations and professionals have developed a network to facilitate impersonal transactions of small-property real estate, essentially shifting the right to develop and sell rural land from the government to farmers and other social entrepreneurs.

Each village in Shenzhen had one or more so-called industrial zones, in which factories were built and investments were received from Hong Kong and other parts of China. Most ... were called joint ventures, meaning that villages contributed factories and investors contributed money, technology, and management. This was the early [phase] of capitalization of rural land in Shenzhen. The Shenzhen government encouraged investment in villages and issued rules, such as guidelines for land leasing rates, on the capitalization of rural land[, notwithstanding the then-effective constitutional prohibition on alienation of land]. [Once investment came], factories were built and villages became [commercial] centers. Millions of migrant workers arrived, primarily to work in factories. In the 198 os, the supply of housing was the responsibility of the local

138. Interim Regulations of the People's Republic of China Concerning the Assignment and Transfer of the Right to the Use of the State-owned Land in the Urban Areas (中华人民共和国城 镇国有土地使用权出让和转让暂行条例) (promulgated by the State Council of the People's Republic of China, May 19, 1990, effective May 19, 1990), available at http:/ /www.lawinfochina. com/display.aspx?lib=law\&id=1 $320 \&$ CGid=.

139. Compensation for the requisitioned rural land is mainly based on its agricultural output, but the government transfers it at urban land market price.

140. See Qiao, supra note 132 , at $45^{-46}$.

141. Id. at $47-5^{1 .}$ 
government, which was unable [to build houses to] even satisfy the housing needs of its own employees . . . . ${ }^{12}$

Migrant workers, who are the main force of Shenzhen's foreigninvestment sectors, were not even counted in the Shenzhen government's plan of housing supply because they were not legal residents of the city. ${ }^{143}$ The huge demand for houses made rural land development and transfer very profitable. But the government still generally prohibited rural land development and transfer, except for allowing villages to rent their land to investors for building factories. Breaking this legal prohibition would be a very profitable change.

But how did the challenge to the legal prohibition occur? A network of members essential to the villages' economic development first blazed the trail of illegal rural land development and transfer. These "supernodes" of the society transmitted the information and practices to other communities. ${ }^{144}$ Eventually, this new property arrangement, though not officially sanctioned, transformed the social relations of the whole city and even led to legal changes. Following are representative stories from interviews with village heads, government officials, and other participants.

A Hong Kong investor, after establishing a business in a Shenzhen village, wanted to buy a plot for his own house. Considering that he had to stay in the village for more than 200 days a year and even had some family there, this need was reasonable. He contacted the village co-op head with his request. The village co-op head had done everything to attract and satisfy outside investors because building joint ventures with outside investors was the village's main business. He was also aware of the government reform of the urban land-use system and expected rural land-use reform to be the next step. As a result, the village co-op head approved this request and sold a plot to the Hong Kong investor-an act illegal at the time.

Social entrepreneurs included not only Hong Kong investors, but also other major players in Shenzhen's rural industrialization. Government agencies responsible for investment approval and land administration, such as the Bureau of Land Administration ("BLA") and the Bureau of Investment Promotion ("BIP"), had observed all the above moves and even studied the legal and policy issues. As a result, they determined that the need for rural land development and transfer was so powerful that it would probably become a trend. The old government housing allocation system had not been able to keep up with the explosive increase in population. Bureau directors were probably troubled by how to house their employees. In a dinner conversation,

\footnotetext{
142. Qiao, Planting Houses, supra note 64 , at $25^{8 .}$

143. See, e.g., Weiping Wu, Migrant Housing in Urban China: Choices and Constraints, 38 URB. AFF. REV. 9o, 99 (2002) ("Migrants are largely excluded from the mainstream housing distribution system, as the linkage between household registration and urban housing is largely intact.").

144. Strahilevitz, supra note 101, at $95^{1-5}$.
} 
a village committee member, after listening to the director of BIP complaining about employee housing, said, "Hey, buddy, why don't you build apartments for your employees on my land?" 145

When a developer, having completing a contract to prepare land for a village development, was told by the village head over dinner that there was no money to pay him, he was offered other village land instead. ${ }^{14^{6}}$ The developer would have preferred cash, but with few choices, gaining the land was the second best deal. Further, through contacts with village co-ops, government officials, and Hong Kong investors, his business would develop if he took the deal. Thus, he accepted this offer. That was how one luxury neighborhood in Shenzhen came about. ${ }^{147}$

Later, the land transactions above encouraged other related people and institutions to buy and sell rural land. The related people included a village head (who had managed all the transactions with Hong Kong investors and government agencies, and who wanted to develop and transfer some of the excess land he was allocated), an official in the BIP (who did not get an apartment from the bureau but had some money), other government employees (who learned about the deal from their friends in the BIP or BLA as a way to resolve their housing shortage), and a migrant worker (who made enough money). ${ }^{14^{8}}$ Government employees participated so widely in rural land development and transfer that the Shenzhen government had to take special measures to address this situation in the 1980 os. ${ }^{149}$

After this cluster of social entrepreneurs made the first move, their friends and relatives followed. The social entrepreneurs were all influential people in their social networks and, thus, had much more weight in influencing the changing of norms. Further transactions encouraged more transactions, and this continued until the formation of a small-property market in Shenzhen ... . ${ }^{150}$

\footnotetext{
145. Interview with a village committee member, in Shenzhen, Guangdong, China (Mar. 10, $2012)$.

146. Interview with an owner of a villa in the neighborhood, in Shenzhen, Guangdong, China (Mar. 10, 2012).

147. Id.

148. Interview with a retired government official (Mar. 13, 2012).

149. Shenzhen government's declarations prohibiting its employees from participating in rural land development were often seen on the first pages of the Shenzhen SEZ Daily in the 1980s, a testament to the prevalence of the practice. See, e.g., Building Houses Illegally, Chen Huang Being Fired from His Office (违章建私房、陈煌被撤职), SHENZHEN SEZ DAILY (深圳特区) (Sept. 8, 1981); The Office of the City Government Declared that All Illegal Buildings Would Be Confiscated (市政 府办公厅宣布继续违章乱建私房一律没收), SHENZHEN SEZ DAILY (深圳特区) (Apr. 3,1985).

15o. Qiao, Small Property, supra note 64 (manuscript at 31) (footnotes omitted). See generally Timur Kuran, Sparks and Prairie Fires: A Theory of Unanticipated Political Revolution, 61 PUB. CHOICE 41 (1989); Randal C. Picker, Simple Games in a Complex World: A Generative Approach to the Adoption of Norms, 64 U. CHI. L. REV. 1225 (1997).
} 
In the latter stage, small-property development and transactions became more professional, with the involvement of lawyers, real estate brokers, and a local bank as market intermediaries. ${ }^{15^{1}}$ As one of us has explained elsewhere:

[D] ifferent levels and different departments of the government are involved in the network of small-property institutions. Some disregard the illegality of small-properties and incorporate them into their official systems in order to effectively address issues such as the monitoring of population migration and the physical site requirements for business operation. Some try to enforce the land law and fight against small property. But without the support of other levels and agencies of the local government, the effect of legal enforcement is limited. Further, bribery becomes a weapon for market participants, who use it to reduce the risk of legal action being taken against them. ${ }^{152}$

The following figure illustrates a typical small-property network. ${ }^{153}$

151. Qiao, Planting Houses, supra note 64, at 263.

152. Id. at 269 .

153. See id. (setting forth a previous version of this diagram). 
Figure 1. A Network of Small Property

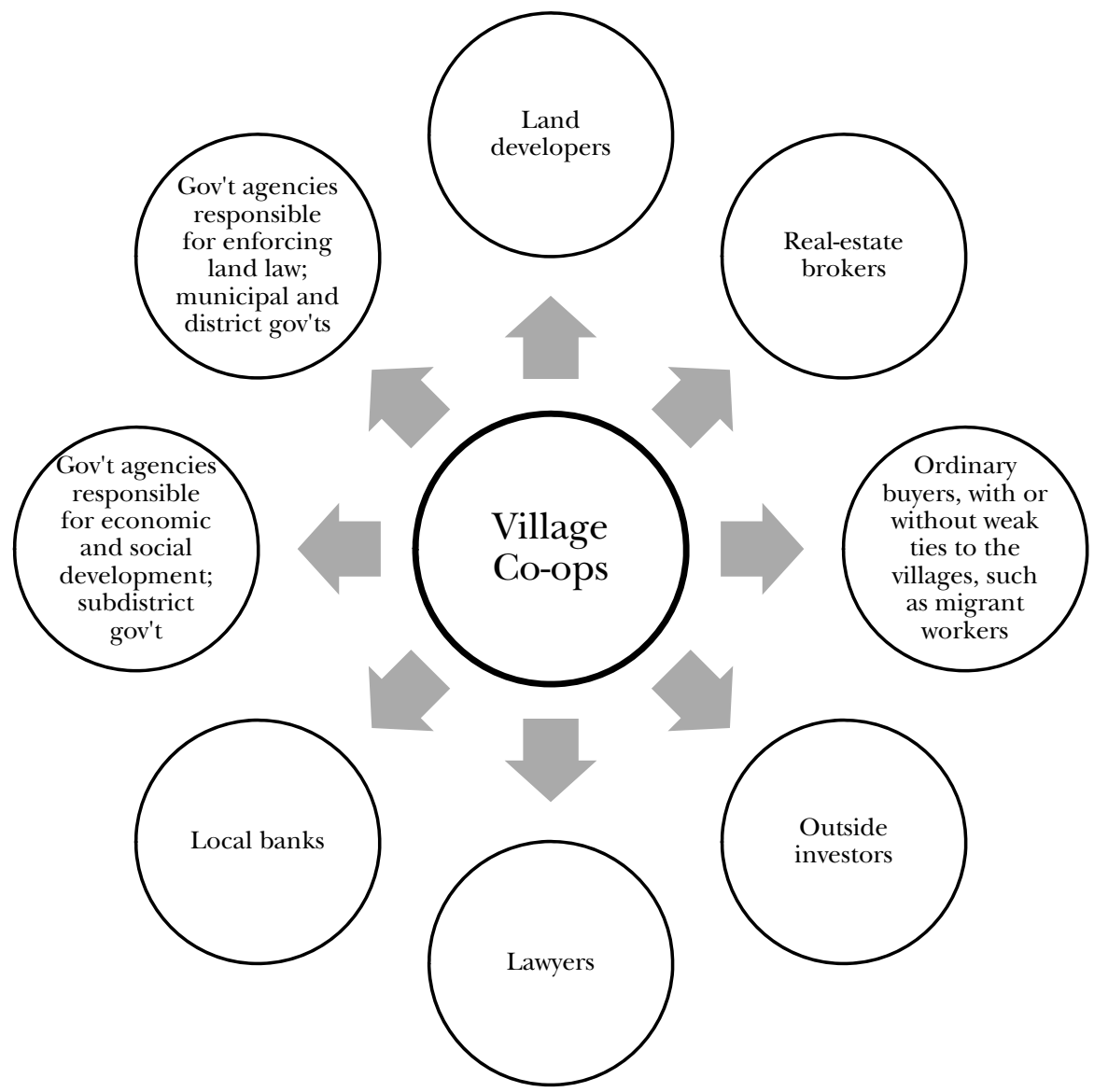

"This expanded network further reduces the risk of government demolition of small properties and increases the credibility of small-property transactions by including local government agencies and branches. It provides a stronger core for the bigger, boundless network through which millions of people engage in impersonal transactions involving small properties." ${ }^{154}$

\section{The Same Market, Differentiated Property Relations}

The emergence of a small-property market has accompanied Shenzhen's rapid urbanization since 1978.155 Facing the same market demand and the same formal institutional structure, however, villages have had different

\footnotetext{
154. Id. at 270 .

155. See Qiao, Small Property, supra note 64 (manuscript at $4-8$ ) (discussing the historical emergence and growth of Shenzhen's small-property market).
} 
destinies. Some villages made their members millionaires and even billionaires, i.e., they gained the city government's recognition of their rights to develop and sell their land, which were cashed out through village redevelopment projects. Some villages' development of rural land was strictly restrained by the city government for environmental and other kinds of considerations, i.e., their rights to develop their land were not recognized and villagers remain poor. Some villages' small-property businesses were warned and fined by the government, and they even became a target of criminal prosecution. And many other villages are still on their way to gaining government-recognized rights to develop and sell their land. ${ }^{15}$

Sometimes, even across a small river, completely different pictures emerge. On one side is a village full of small-property construction where villagers have shown no respect for the legal prohibition on rural land development and transfer and have "planted" as many houses as possible in each vacant plot. ${ }^{157}$ On the other side is a village in which the village co-ops have restricted construction because these co-ops chose to apply for legal rights to develop and sell their land from the local government.

In one case, Wanfeng village and its leader were prosecuted for bribing government officials to cover up their small-property business, and the leader was also convicted for participating in a criminal organization, of which the main business was buying and selling small property. In another case, Zhangshubu village co-op from time to time took action "in the name of law" in their bargaining for legal property rights with the government and with a hold-out couple who refused to submit their "nail house" (the Chinese term for such buildings because they stick out and are difficult to remove, like a stubborn nail) to the village co-op for redevelopment. ${ }^{15}$

From a purely economic or legal perspective, there should be no difference in small-property development across different villages. Though, there may be a difference in the degree of market development, the typical Demsetzian story would be that private land rights emerged in response to the increasing demand for housing. ${ }^{159}$ But this story would raise a question as to why some villages go white and some go black. ${ }^{160}$ The reasons cannot be

156. See SOUTHERn METROPOLIS DAILY (南方都市报编著), NO INTRA-CITY VILLAGE IN THE FUTURE (未来没有城中村) (2011).

157. See Qiao, Planting Houses, supra note 64, at 255 .

158 . For a photograph of a Chinese "nail house," see Stubborn as a Nail: China Residents Who Refuse to Move, ABC NEWS, http://abcnews.go.com/International/photos/stubborn-nail-chinaresidents-refuse-move-19827908/image-19828396 (last visited Apr. 24, 2015). For a scholarly discussion of such a case, see Shitong Qiao, Stopping Land Grabs by Privatization in Rural China: Illusion or Reality? (n.d.) (unpublished manuscript) (on file with author).

159. See Demsetz, supra note 28 , at $35^{6}$.

16o. Chinese use color to distinguish the legality of organizations and their activities. For example, "black" means illegal and often involves mafia marked by violence and crime, and "white" means legal and official recognition. For most occasions, small property is "grey," i.e., between black and white. 
sought solely from the market or legal system, but must also be sought by examining the social relations within a village. In particular, one should examine the relations between village co-op leaders and its members and external social relations of the village co-op, especially with varying levels of the government. ${ }^{161}$

\section{CONCLUSION}

This Essay does not set out to challenge the information cost theory of in rem property, and the Essay does not argue that the right to exclude is not important. We do, however, believe that the in rem property theory undervalues the social relationships in which property rights are embedded. In the Chinese context, the question of who owns the land is too difficult to answer, and because of this, we decided to go a different route. We find that the concept of relational property fits better into the landscape of Chinese rural land reform and other evolutionary stories of property rights that have been ignored in law and economics. Since there is no simple and uniform answer to the comparative institutional capacities of governments, communities, or markets, ${ }^{162}$ it is better to evaluate the related institutions and institutional stakeholders comprehensively in a particular context before we decide which form of property rights should and could prevail. That is why we find the concept of relational property helpful. This relational property concept is an attempt to bring social relations, which law and society scholars are enthusiastic about, to the heart of the economics of property law. The cases we present do not necessarily represent the most efficient property systems, but they represent social reality and deserve greater attention.

161. For more details, see Qiao, supra note 132, at 154-206.

162. See NeIL K. Komesar, Imperfect Alternatives: ChoOsing InStitutions in LAW, ECONOMICS, AND PUBLIC POLICY 271-76 (1994). 